\title{
A Systematic Literature Review on Utilization of Gamification in Nursing
}

\author{
Ji Won Oak \\ Department of Nursing, Tongmyong University, Busan, Korea \\ jiwonoak@gmail.com
}

\begin{abstract}
This paper was investigated the nursing research related to gamification and analyze the contents and effects of the experimental research to examine its effect. A systematic literature review was conducted. The articles were searched electronically using the data base with the key words of "gamification" or "gamified" and "nursing". Finally, six studies were selected among 80 studies. The study was conducted mostly by health care professionals including nursing students $(n=4)$ and education subjects $(n=5)$. 'Reward' was the most common gamification mechanism used in the study, and all studies were combined with various gamification mechanisms. In nursing education where participation and motivation of the subject is important, gamification can play an important role in educational effect. Nursing researchers' interest in gamification is needed in the future, and it is necessary to develop scenarios suitable for educational situations and to check their effectiveness.
\end{abstract}

Keywords: Gamification, Nursing, Education, Systematic, Literature, Review

\section{Introduction}

The gamification announced in 2010 is a motivation method widely used in disital games, applying game mechanism to promote people's interest and immersion in activities [1][2]. Game mechanics and game thinking that are used to create game fun such as score, level up, ranking, competition, challenge performance, and reward that are commonly seen in digital games induce participants' interest and motivation and promote immersion to improve the effectiveness of education [3]. When gamification applied to education, it is not just a fragmentary concept that gives points, rewards and badges to the learning experience, but it also uses game-based skills and thinking to attract people, motivate them, and helps solve the problems [4]. Therefore, in the nursing education, students will find out what problems they have by analyzing and evaluating their own nursing practice. Students will also be encouraged to practice their skills on a recurring basis, encourage interest and involvement, and encourage active, self-directed learning. It is expected that students will be able to receive enhanced nursing education by improving their self-directed ability and self-directed learning ability.

Thus, the application of gamification in nursing education is meaningful as one of the new educational methods, but it has not been activated and it has not been reported in Korea. Therefore, it is necessary to confirm the current status of gamification in nursing education and to examine its effect. The purpose of this study was to investigate the effects of

Article history:

Received (September 2, 2017), Review Result (November 6, 2017), Accepted (December 10, 2017) 
gamification on nursing research and to analyze the effects and interventions of experimental research to examine its effects. This study is to contribute to the development of nursing research by increasing understanding and interest about gamification applied to nursing research and suggesting ways of using gamification in nursing science.

\section{Data collection and analysis methods}

In this study, we selected the experimental study which confirmed the effect of gamification among the gamification related studies in nursing.

From May 16th to May 31st, 2017, we used keywords "gamification" or "gamified" and "nursing". Data were collected by searching six databases (PubMed, CINAHL, Science Direct, EBSCO and Google scholar). There was no publication date limitation, and only English journals were selected for research. The selection criteria for the paper are as follows: (1) At least one gamified approach was included. (2) The research was qualitative or quantitative research. (3) This study was original and was not a review of other studies.

A total of 80 studies were conducted on gamification in nursing. Of these, 52 researches were extracted excluding 13 duplicates, and 15 non-original texts. In addition, 33 nointervention researches, 1 non-English journal, and 22 non-nursing researches were excluded, and the final 6 researches were selected [Figure 1].

The results of the study were analyzed based on the guidelines for the review of systematic literature, which was proposed in 2008, and the content of arbitration and the effects of arbitration were analyzed based on the guidelines of the systematic reviews and meta-analysis [5].

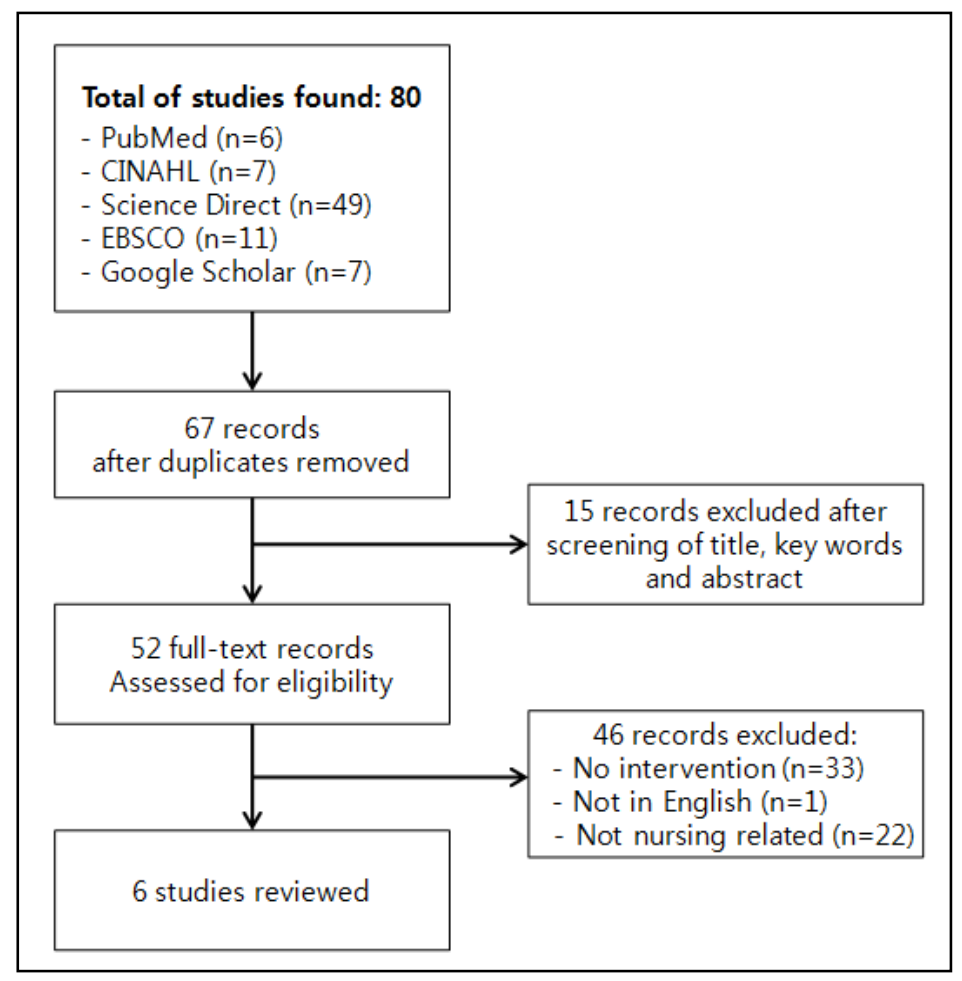

Figure 1. Flowchart of study inclusion 


\section{Results}

Six papers were selected for final analysis. Research has been published in Europe and the Americas, all since 2016. The subjects of the study were health care professionals including nursing students $(n=4)$. The subjects were the most educated subjects $(n=5)$, of which there were two studies to change habits [Table 1].

Table 1. Purpose and target groups

\begin{tabular}{|c|c|c|c|}
\hline No & Reference, Country & Purpose & Target group \\
\hline 1 & $\begin{array}{l}\text { Ingadottir etc. } \\
\text { (2017), Iceland [9] }\end{array}$ & $\begin{array}{l}\text { To learn about postoperative } \\
\text { pain management }\end{array}$ & $\begin{array}{l}20 \text { surgical patients: Postoperative pain; } \\
\text { Facebook advertisement }(\mathrm{n}=11) \text {, snowball } \\
\text { method }(\mathrm{n}=9)\end{array}$ \\
\hline 2 & $\begin{array}{l}\text { Lapão etc. (2016), } \\
\text { Portugal [10] }\end{array}$ & $\begin{array}{l}\text { To improve nurses' hand } \\
\text { hygiene compliance in an } \\
\text { ICU ward }\end{array}$ & 4 nurses from the ICU ward \\
\hline 3 & $\begin{array}{l}\text { Trimblett (2016), } \\
\quad \text { Canada [11] }\end{array}$ & $\begin{array}{c}\text { To jurisprudence education of } \\
\text { LPNs }\end{array}$ & 189 LPNs: Exp. group $(n=88)$, Con. Group \\
\hline 4 & $\begin{array}{l}\text { Mawhirter and } \\
\text { Garofalo (2016), } \\
\text { USA [12] }\end{array}$ & $\begin{array}{l}\text { To engage students and } \\
\text { encourage reflective self- } \\
\text { assessment of skills }\end{array}$ & $\begin{array}{l}18 \text { nursing students: the } 1 \text { st. semester }(n=7) \text {, } \\
\text { the } 4 \text { th. }(n=11)\end{array}$ \\
\hline 5 & $\begin{array}{c}\text { González-Salvado } \\
\text { etc. (2016), Spain } \\
{[13]}\end{array}$ & $\begin{array}{l}\text { To improve hands-only CPR } \\
\text { among untrained citizens }\end{array}$ & $\begin{array}{l}\text { 155: laypeople }(\mathrm{n}=81) \text {, health care } \\
\text { professionals }(\mathrm{n}=74)\end{array}$ \\
\hline 6 & $\begin{array}{l}\text { Gonzalez etc. } \\
\text { (2015), Spain [14] }\end{array}$ & $\begin{array}{l}\text { To improved healthy lifestyle } \\
\text { habits }\end{array}$ & $\begin{array}{c}20 \text { children with a BMI indicative of } \\
\text { overweight: aged 8-12/ Exp. group (11), Con. } \\
\text { group (9) }\end{array}$ \\
\hline
\end{tabular}

As for the intervention methods, 5 studies were mostly single-ended studies, and 16-week studies were conducted. The platform used in the intervention was the most popular game formats $(n=3)$. The intervention effect was confirmed in all studies [Table 2].

The mechanism of gamification used in the study was 'Reward', which was used in section 6 , followed by 'Point'. Six studies were conducted by introducing three to eight gamification mechanisms.

\section{Conclusion}

A total of 80 papers were searched in the field of nursing, and many of these studies were confirmed to be research on the contents of scenarios in order to explain or apply the concept of gamification rather than experimental research. Addition, there were only six papers which were searched in the field of nursing but excluding medical researches or researches nursing students by control group, which included college students of various majors. The concept of gamification is a new concept introduced in 2010, and gamification applies an important role in increasing positive effects such as motivation and participation rate by applying advantages of game. Research in the field of nursing has been reported since 2016, suggesting that there will be more studies applying gamification in the field of nursing. 
Table 2. Intervention effects

\begin{tabular}{|c|c|c|}
\hline No. & Intervention & Effects \\
\hline 1 & $\begin{array}{l}\text { Serious game (Postoperative Pain Management } \\
\text { Game, 90min) in Tablet }\end{array}$ & $\begin{array}{l}\text { A serious game can be an efficient method to learn } \\
\text { about pain management; it can improve knowledge } \\
\text { and is appreciated by users. }\end{array}$ \\
\hline 2 & $\begin{array}{l}26 \text { beacons fixed in the rooms' doors, in each } \\
\text { alcohol-based hand rub container, in each sink } \\
\text { and in each bed. smart tags carried by nurses. }\end{array}$ & $\begin{array}{l}\text { The simulation in a non-clinical setting by the } \\
\text { researchers presented good results. The system } \\
\text { worked accordingly to our expectations, returning a } \\
\text { hand hygiene (HH) compliance rate of } 100 \% \text {. }\end{array}$ \\
\hline 3 & $\begin{array}{l}\text { The CLPNBC portrayed many nursing } \\
\text { situations through recorded scenes played by } \\
\text { real life actors and video scripts with voice } \\
\text { overs (Jurisprudence Pilot Project). } \\
\text { One group was given the gamified education } \\
\text { before moving onto the exam while the other } \\
\text { group received no education and went straight } \\
\text { to the exam. }\end{array}$ & $\begin{array}{l}\text { There are three different elements of gamification } \\
\text { that can lead to engagement: immersion, intrinsic } \\
\text { and extrinsic motivation and competition. } \\
\text { Gamification had a positive influence on some of } \\
\text { the LPNs to change their attitudes and behaviors } \\
\text { around their own nursing practice. }\end{array}$ \\
\hline 4 & $\begin{array}{l}\text { Patient safety simulation } \\
\text { Each team (two or three) performed three real- } \\
\text { time, high-definition simulations using a human } \\
\text { patient simulator. } \\
\text { The } 1 \text { st. round scenario ( } 60 \text { seconds, patient } \\
\text { safety themed) } \\
\text { The } 2 \text { nd. second ( } 5 \text { minutes, wound drainage } \\
\text { and medication calculation) } \\
\text { The 3rd. round ( } 15 \text { minutes, to complex } \\
\text { awareness, arrhythmia recognition and patient } \\
\text { rescue) }\end{array}$ & $\begin{array}{l}\text { One hundred percent of the participants expressed } \\
\text { that the learning experience was beneficial, } \\
\text { engaging, and decreased their fear of the } \\
\text { unexpected. } \\
\text { All students expressed increased readiness for the } \\
\text { clinical experience. }\end{array}$ \\
\hline 5 & $\begin{array}{l}\text { Training: very brief practical training (b5 } \\
\text { minutes): using Laerdal Skill Reporter software } \\
\text { on a manikin } \\
\text { Test: during a 2-minute chest compression (CC) } \\
\text { test }\end{array}$ & $\begin{array}{l}\text { CC-CPR performance assessed by the QCPR } \\
\text { formula as previously described was above the } 70 \% \\
\text { goal for both groups. } \\
\text { The HCP scores were statistically significantly } \\
\text { higher, but the scores of the percentage of CCs with } \\
\text { full-chest recoil were not statistically significant, } \\
\text { but the scores of the laypeople were higher. }\end{array}$ \\
\hline 6 & $\begin{array}{l}\text { The training program consists of } 16 \text { group } \\
\text { sessions ( } 90 \mathrm{~min} \text { ) } \\
\text { a) Group sessions for children in a school } \\
\text { setting ( } 90 \text { min, twice a week): training ( } 30 \\
\text { min), motor games ( } 40 \text { min) and TANGO: } \\
\text { Hactive videogame ( } 20 \text { min) twice a week. } \\
\text { b) Individual sessions for children at home ( } 45 \\
\text { min, twice a week): commercial active Wii Fit } \\
\text { Plus videogame ( } 30 \text { min) and collaborative } \\
\text { multiplayer online videogame (Pirate Island e } \\
15 \text { min). } \\
\text { c) Family training ( } 90 \text { min). }\end{array}$ & $\begin{array}{l}\text { Increased motivation through gamification } \\
\text { intervention program, can be checked by the results } \\
\text { obtained on the emotions of the Emodiana, plus the } \\
\text { results of the degree of compliance with the } \\
\text { activities planned for the home. } \\
\text { Improved healthy lifestyle through a program that } \\
\text { combines training, motor play and active video } \\
\text { games, both at home and at school, there was an } \\
\text { improvement in the lifestyle of the children through } \\
\text { our intervention program, as we see an } \\
\text { improvement in the quality index of the } \\
\text { Mediterranean diet (KIDMED) in the experimental } \\
\text { group versus the control group. }\end{array}$ \\
\hline
\end{tabular}

Research using gamification requires a multidisciplinary approach, and research combining both quantitative and qualitative research needs to be activated [6]. In the study analyzed in this study, there were two studies of the mixed method including the qualitative research method such as the interview, and the process of asking the opinion of the subject was added in the quantitative research.

In this study, the gamification mechanism analysis was conducted based on the guidelines of the gay mission mechanism proposed by Bunchball [7], a leading US gaming company. As a result of this study, it was confirmed that 3 to 8 elements of gamification were applied in the 
program composition. 'Reward' is a factor used in all studies. 'Reward' is a factor to stimulate the participation rate by stimulating human needs or desire. It is used to stimulate the need of the target in the research of the nursing field and to increase the participation rate of intervention. In each study, we applied different combinations of elements of gamification. This is probably due to the good performance when the five factors of game mechanics and the six factors of game dynamics are combined properly [2]. Therefore, in order to apply gamification to nursing education in the future, it is necessary to construct a scenario by taking into consideration the contextual combination of two detailed factors according to contents of education and subject.

Research that applied gamification in nursing as well as in Korea is considered to be at an early stage. In nursing education where participant's participation and motivation are important; gamification can play an amplifying role in educational effect. The results of this study are expected to increase the interest of nursing researchers in gamification, and to develop scenarios according to the situation and to confirm their effectiveness.

\section{Acknowledgements}

This work was supported by the National Research Foundation of Korea(NRF) grant funded by the Korea government(MSIP; Ministry of Science, ICT \& Future Planning) (No. NRF-2017R1C1B5017641).

\section{References}

[1] J.T. Kim, "Dynamical model for gamification of learning(DMGL): Simulation of the four primary factors improving educational effectiveness in learning games," Ph.D. dissertation, Chung-ang University, (2014).

[2] H.L. Lee, J.H. Woo, M.S. Park, D.Y. Lee, and E.J. Jeong, "A research on the effective development of gamification through case study-based on game mechanics and game dynamics," Korean Society for Computer Game, vol.27, no.1, pp.141-151, (2014)

[3] A. Khasianov, I. Shakhova, and B. Ganiev, "Gamification in higher education: Kazan federal University primer,” eLearning \& Software for Education, Vol.1, pp.519-522, (2016)

[4] K.M. Kapp, "The gamification of learning and instruction: Game-based methods and strategies for training and education," NY: John Wiley \& Sons, Inc. (2012)

[5] A. Liberati, D.G. Altman, J. Tetzlaff, C. Mulrow, P.C. Gøtzsche, J.P. Ioannidis, M. Clarke, P.J. Devereaux, J. Kleijnen, and D. Moher, "The PRISMA statement for reporting systematic reviews and meta-analyses of studies that evaluate healthcare interventions: Explanation and elaboration," The British Medical Journal, vol.338, (2009) DOI:10.1371/journal.pmed.1000100

[6] B. Kwon and C. Lyou, "The meta-analysis of domestic gamification research: Status and suggest," Korea Humanities Content Society, vol.39, pp.97-124, (2015)

[7] Bunchball, Inc., "Gamification 101: An introduction to the use of game dynamics to influence behavior," California: Bunchball, Inc. (2010) 
A Systematic Literature Review on Utilization of Gamification in Nursing

This page is empty by intention. 